\title{
Protection of the Right to the Freedom of Speech and Information in the Digital Era
}

\author{
Natalya Blokhina ${ }^{1, *}$ Nina Olinder ${ }^{1}$ \\ ${ }^{1}$ Department of Constitutional and Administrative Law, Togliatti State University, Togliatti 445667, Russian Federation \\ * Corresponding author.E-mail: tolrec@mail.ru
}

\begin{abstract}
The article deals with the issues of legal regulation of the system of protection of rights to freedom of speech and information in the digital era. Given the recent changes in the economy and society due to the globalization and the rise of the information and communication technologies (ICT), the ways how opinions can be expressed and the information can be shared extrapolated considerably. However, the easiness of sharing information using the Internet and social networks should be overbalanced with the protection of the freedom of speech and information. The article analyzed domestic and international ways of protecting human rights on the protection of the right to freedom of speech and information in the Russian Federation and abroad.
\end{abstract}

Keywords: Protection of rights, digitalization, freedom of speech and information, European Court of Human Rights.

\section{INTRODUCTION}

Over time, the position of a person in society has changed significantly, beliefs, values, priorities have changed. A variety of factors influenced the change in the value system. The modern world has once again found itself at a point of bifurcation, before choosing a further social path.

The rapid development of information technologies promises a transition to a new social system, freed from the ideas of a traditional industrial society, from its contradictions. Digital technologies undoubtedly have high economic potential, in connection with which states have entered the struggle, or, the so-called, leadership race in the field of digital transformation. The fascination with achievements, the thirst for their early implementation leads to the fact that law, as never before in its history, lags behind innovations, turns out to be incapable of their legal support. It so happened in the history of law that a certain phenomenon or category should not only appear, but also be comprehended, and formally introduced into public life, integrated into the existing legal order.

Digitalization is mercilessly gaining momentum, the world will definitely change, but the issues of legal regulation of the upcoming changes are not yet sufficiently resolved. In such conditions, the relevance of strategies that determine the immutable values of society and law increases. The declared task for the new millennium - building an information society, has as its substantive basis significant communication changes ("man - man", "man - technology", "technology technology"), as well as changes in the approach to information as the main, most valuable resource and a completely new approach to data aggregation. It seems that access to Big Date will provide a breakthrough development of the commercial sector, non-profit structures, and significantly change the sphere of public administration. However, Big Data is not only a resource that has advantages, but also serious disadvantages, and in some cases entails threats and problems, including the uncontrolled collection of information about users of telecommunication networks, the loss of control over personal data and their confidentiality, the imposition of ideologies of violence, informational discrimination of both individual citizens and their associations. Until now, signs of discriminatory differentiation were mostly age, gender, property. Digitalization can introduce new causes of inequality, even in such areas as labor relations, labor and employment markets, access to credit products, insurance, etc., not to mention the uneven distribution of new technologies and access to them.

\section{HISTORY OF HUMAN AND CIVIL RIGHTS}

Human and civil rights and freedoms have a long and complex history of their formation and their conquest of a priority social place. The problem of protecting the rights of citizens and organizations continues to exist in all countries. In the Russian Federation, the formation of a system for protecting human rights is complicated not only by their relatively recent recognition, but also by the unhurried formation of a mechanism for implementation. In confirmation of this, the long-term formation of the institution of ombudsmen for human rights in the constituent entities of the Russian Federation, moreover, the process of introducing these posts was completed 
only thanks to the intervention of the central federal bodies of state power and the adoption of federal laws.

At the global level, there is a multi-level international system for the protection of human rights, in which the UN plays the leading role. The human rights protection system consists of interrelated elements - principles, methods and forms of protection. In our opinion, in the conditions of a technological revolution, a deep analysis is needed not only of human and civil rights, but also of the entire system aimed at protecting them. Particularly noteworthy is the group of so-called informational human rights and freedoms and issues of their limitations. Certain problems have already been raised by special rapporteurs and submitted for discussion in the United Nations General Assembly.

Communication is an integral part of our life, therefore the right to freely express one's thoughts, freedom of speech, the right to freely seek, receive, transmit, produce and disseminate information is an important group of rights, often closely intertwined or inseparable from many other human and civil rights. Thus, freedom of thought and freedom of speech are inseparable from the right to use the native language. Thoughts can be expressed in various ways, and ideas can be embodied in creativity - paintings, photography, sculpture, performances, through installations, etc., which are the same source of information and a means of communication. Often, such methods of transmitting information have the strongest psycho-emotional influence, which cannot always be achieved with a word. For example, Marina Abramovich's performance, presented to the visitors of the Balkan Baroque exhibition in 1997, when the artist sat in a pile of bones for four days for six hours, washing them and singing traditional Balkan songs. The performance was dedicated to the war in Yugoslavia, the horrors and suffering of people.

In June 1963, a photograph of a self-immolation by the Buddhist monk Thích Quảng Đức against religious persecution in Vietnam literally shocked European and American society. US President Kennedy said in this regard: "Never has newspaper photography caused such great excitement around the world".

\section{FREEDOM OF SPEECH AND THOUGHT IN RUSSIA}

Freedom of thought, self-expression cannot be absolute, some ideas pose a significant danger to society, carry destruction and a threat to order. Part 3 of Art. 55 of the Constitution of the Russian Federation contains a provision that makes it possible to restrict the rights and freedoms of man and citizen as necessary in order to protect the foundations of the constitutional order, morality, health, rights and legitimate interests of others, to ensure the defense of the country and the security of the state. Part 2 of Art. 29 of the Constitution of the Russian Federation prohibits the propaganda of any kind of superiority of people based on differences of a social, racial, national, religious or linguistic nature.

Article 44 of the Constitution of the Russian Federation, which guarantees freedom of creativity, should be regarded as a derivative of freedom of thought. The constitutions and laws of most countries, proclaiming freedom of thought, speech, creativity, information, at the same time establish the boundaries of what is permitted, the limits of distribution and the purpose of use. In Art. 39 of the Constitution of Bulgaria of July 12, 1991 simultaneously refers to the granted right and indicates the unacceptable purposes of using the right. It is noteworthy that part 1 of this article speaks specifically about the right of everyone to express an opinion and specifies in detail various ways for this "through a word - in writing or orally, through sound, image or otherwise."

Freedom of thought and speech is an inalienable human right, since thought itself is a natural innate property, and through the word it gets real embodiment, is objectified in the external world. However, it should be borne in mind that not "everyone", according to the terminology of the Constitution of the Russian Federation, can become a subject of the right to freedom of speech, reaching a certain age and state of sanity will be important for the legal characteristics of the owner of freedom and its full implementation.

Quite a lot of dissertations have been written and scientific research in the field of law has been carried out on the protection of freedom of speech and information, however, there is no task in this topic to come to a consensus, to unify approaches to the concept, but there is a need to study the elements of the protection system for their effective practical use. In some works, for example, in Dubrovina's dissertation research, the protection of the right to freedom of thought and speech is defined as the activity of competent authorities carried out on the basis of the law and in the prescribed manner in connection with an encroachment that may or has already resulted in a violation of this right [1, 23 p.].

The purpose of protecting the right in question should be to prevent an encroachment on it (prevention), to stop its violation (suppression), to restore the violated right, to apply various restrictive and coercive measures.

\section{PROTECTING RIGHTS AND FREEDOMS IN THE DIGITAL ERA}

Ways to protect rights and freedoms are often classified on different grounds. You can find the division 
into jurisdictional and non-jurisdictional. In another version of the classification, we see such methods of protection as state; activities of the human rights ombudsman of the Russian Federation or a subject; local government bodies; public associations, human rights organizations; international human rights bodies; selfdefense [2, pp. 168-169]. The proposed classification options can be called "institutional".

The allocation of "self-defense" for the group of information rights is quite natural, since according to the meaning of constitutional prescriptions and other legislative acts, for example, the Civil Code of the Russian Federation, each person is entitled to defend his rights and legitimate interests in all ways not prohibited by law. However, the controversial nature of this element of protection of the right to information and freedom of speech consists in determining the actions that relate to it. For example, on the one hand, a citizen's appeal to the same Ombudsman on the fact that there has been a violation of freedom of speech, on the one hand, is selfdefense, since a person uses the right granted to him. On the other hand, this appeal gives rise to the emergence of special legal procedures performed by the authorized person or representatives of his office. The citizen's appeal to the judicial or other law enforcement agencies also initiates proceedings in defense of the law. In this regard, it seems that all other methods of protection that are not prohibited by law that are not associated with direct appeal to state authorities, local self-government bodies, and international instances should be included in the ways of self-protection by a citizen of his right to freedom of speech and information etc.

Also, the system of protection of the right to freedom of speech and information is ranged by levels: international, domestic (federal, regional (the level of the subject of the Russian Federation, municipal) [2, 168 p.].

We adhere to the point of view of subdividing the entire system of protection of the right to freedom of speech and information for protection by the state (in conjunction with international remedies); to public protection and self-defense [1, $22 \mathrm{p}$.].

State protection always seems to be more effective. The main constitutional obligation of the state, following from Article 2 of the Constitution of the Russian Federation, is to recognize, observe, and protect the rights and freedoms of man and citizen. This provision requires the state to create an efficient and effective mechanism for the implementation, protection and protection of all, without exception, human and civil rights and freedoms, including "information rights". At the moment, the state mechanism for protecting the right to freedom of speech and information includes bodies of all three branches of government: legislative, executive and judicial power, as well as the President of the Russian Federation, the Prosecutor's Office of the Russian Federation.
The President of the Russian Federation acts as the guarantor of human and civil rights and freedoms in Russia, as provided for in Art. 80 of the Constitution of the Russian Federation. This is also evidenced by practice, since a fairly significant part of the issues related to the resolution of problem situations of protection of human and civil rights and freedoms is resolved at the level of the President of the Russian Federation or his staff.

Also, the activities of the Prosecutor's Office of the Russian Federation are of great importance. According to the Federal Law "On the Prosecutor's Office of the Russian Federation", the Prosecutor's Office performs the function of overseeing "the observance of the Constitution of the Russian Federation and the execution of laws in force on the territory of the Russian Federation" [3]. Prosecutors accept complaints from citizens about violation of their rights and freedoms, on the basis of which inspections are carried out, and issue acts of prosecutorial response. Prosecutors are empowered to apply to court both to protect the rights, freedoms and legitimate interests of a citizen, and in the interests of an indefinite circle of persons.

In the system of state protection of human rights and freedoms, an important place is occupied by the activities of the internal affairs bodies, their competence includes a number of law enforcement measures aimed at preventing violations of human and civil rights and freedoms, eliminating obstacles to their implementation.

\section{LEGAL RESPONSIBILITOES FOR THE VIOLATION OF FREEDOM OF SPEECH AND INFORMATION}

The legislation of the Russian Federation establishes measures of legal responsibility for violation of "information" rights and freedoms, for example, Art. 5.5 of the Code of Administrative Offenses of the Russian Federation [4] (hereinafter referred to as the Code of Administrative Offenses of the Russian Federation) provides for liability for violation of the procedure for mass media participation in information support of elections. According to Art. 5.26 of the Code of Administrative Offenses of the Russian Federation may be followed by bringing to administrative responsibility for violation of the legislation on freedom of conscience, freedom of religion and religious associations. The object of such an offense is social relations arising in connection with the exercise by a person and a citizen of the right to freedom of conscience, freedom of religion, participation in the activities of religious associations. In part 2 of the same article, the direct object of the encroachment is highlighted - religious, moral and atheistic, worldview views and beliefs, as well as public order. The exclusive jurisdiction of cases of administrative offenses and under Art. 5.5 and under Art. 
5.26 of the Administrative Code of the Russian Federation is assigned to judges. Although, there are proposals to change the jurisdiction and to classify some offenses, for example, part 4 of Art. 5.26 to the activities of the internal affairs bodies. We, in turn, do not support the introduction of dual jurisdiction, since any restrictions in the field of human and civil rights and freedoms must be under the control of the judiciary.

Responsibility for violation of the right to freedom of information and freedom of speech can also come under several articles of the Criminal Code of the Russian Federation. First of all, it is Art. 140 of the Criminal Code of the Russian Federation "Refusal to provide information to a citizen", which provides for criminal liability for the unlawful refusal of an official to submit documents and materials directly affecting the rights and freedoms of a citizen, or the provision is incomplete or knowingly false. According to Art. 136 of the Criminal Code of the Russian Federation for violation of the equality of human and civil rights and freedoms provides for a criminal penalty. As for the activities of the media, here it is necessary to point out Art. 144 of the Criminal Code of the Russian Federation, which provides for criminal liability for obstructing the legitimate activities of a journalist.

Encroachments in order to obstruct the collection of information and its further dissemination against journalists with a special status are not permissible. Often, journalists, preparing stories for coverage on television, are faced with aggressive behavior of citizens who are dissatisfied with the fact that they have become participants in television news. In July 2016, in the city of Artemovsk, Sverdlovsk Region, journalists were attacked when they were recording, on the instructions of the editorial board, a video about animals at an enterprise that caught stray dogs and cats. The coverage of this problem in the media was supposed to be the result of a check by the All-Russian Popular Front of the type of activity for trapping stray animals - checking the confirmation or refutation of information about violations. Employees of the enterprise beat the correspondent and the operator, broke the camera and took away the drive [5].

The Commissioner for Human Rights in the Russian Federation acts as a special state entity acting in order to ensure guarantees of state protection of the rights and freedoms of citizens, including the right to freedom of speech and information. Its activities are regulated by a special constitutional law - Federal Constitutional Law of February 26, 1997 No. 1-FKZ "On the Commissioner for Human Rights." The Commissioner for Human Rights in the Russian Federation considers complaints from citizens of the Russian Federation and all persons who do not have Russian citizenship, but who are in the country. The status of the Ombudsman presupposes the independence of the activities carried out by him from any authorities, his non-accountability. The results of the activities of the Commissioner for Human Rights are reflected in the annual report, which is sent to the President of the Russian Federation, the Federation Council and the State Duma, the Government, the Constitutional Court, the Supreme Court, the Prosecutor General, and the Chairman of the Investigative Committee. In the opening remarks of his report on the results of 2019, the Commissioner for Human Rights in Russia for 2019 Moskalkova touched upon the problem of finding a new toolkit for responding to challenges and threats to human rights in modern realities, which is undoubtedly of great relevance not only for our country, but throughout the world. The Ombudsman's report cites sociological research data, according to which the percentage of compatriots surveyed who considered freedom of speech as one of the most important values in 2019 was $24 \%$ (in $2018-20 \%$ ). As for the sources of information, most often these are television media and news sites on the Internet. Every year, the Internet is increasing its presence in people's lives as a source of information: at the end of 2019 , the share of Russians who received news information mainly on the Internet was $45 \%$, and (in 2017 - 41\%) [6].

Another trend in this area is the increase in the number of respondents who do not trust or question the reliability of information received from the media (from $24 \%$ in 2018 to $31 \%$ in 2019). According to the Ombudsman, "a critical attitude towards information from the media makes it necessary to improve the quality of news content, strengthen the independence of the media, and ensure the professional rights of journalists" [6].

As for the appeals to the Commissioner for Human Rights regarding violations of the right to information and freedom of speech, most of them related to the professional activities of a journalist (18 messages), including those related to obstruction of the professional activities of Russian journalists abroad (Ukraine, Lithuania and some other states). Among violations of the rights of journalists inside the country, the Human Rights Ombudsman in the Russian Federation noted situations with the dismissal of the editor-in-chief of the newspaper "Uryupinskaya Pravda" Shushlebina due to the incorrect placement of photos of politicians, the dismissal of journalists of the Kommersant newspaper, accusations of drug trafficking journalist Golunov [6].

The activities of the state to protect the right to freedom of speech and information are complemented and strengthened by the existence of international institutions. The most important place in the system of protection of human and civil rights and freedoms is occupied by the European Court of Human Rights. The mechanism of interaction of the ECHR with the courts of the countries of the Council of Europe has recently undergone changes, it is expected that the new procedure will facilitate faster and more qualitative consideration of cases by domestic courts for the protection of human 
and civil rights and freedoms, which will reduce the number of complaints coming directly to consideration to the European Court of Human Rights, will reduce the terms of consideration and improve the quality of the decisions made. The ECHR now has an advisory function on requests from the highest judicial authorities of the Council of Europe member states on the interpretation of the provisions of the European Convention on Human Rights. In our opinion, this situation will contribute to the formation in Europe of a uniform culture of human rights, the development of uniform tools in the protection system. In 2019, another innovation appeared in the practice of the ECHR concerning the pre-trial settlement of a dispute between a state and a citizen. In cases where the proposal to resolve the dispute is accepted by the respondent state, but is rejected by the party to the complainant, then such a case will be excluded from the list.

In 2019, 19 decisions were made in relation to Russia on freedom of speech and the exercise of the right to information. In these cases, the ECHR found a violation of Part 2 of Art. 10 of the Convention for the Protection of Human Rights and Fundamental Freedoms, the total amount of the awarded compensation was 40611 euros, a significant part of the cases are complaints from journalists, namely, six cases were related to the consideration of defamation claims in courts against the latter (responsibility for disseminating defamatory information) [7-14].

It is customary to include municipal bodies in the system of bodies that ensure the protection of the right to freedom of speech and information. According to Part 1 of Art. 130 of the Constitution of the Russian Federation, local self-government provides an independent solution by the population of issues of local importance, ownership, use and disposal of municipal property. It seems that, due to its specifics, the activities of municipal bodies are not so effective in ensuring the right to freedom of speech and information.

Public associations in the field of freedom of speech and information and human rights organizations in general play an important role in protecting human rights in the state. The foundations of the activities of such organizations are provided for in the Constitution of the Russian Federation. So, according to Part 1 of Art. 30 of the Constitution of the Russian Federation, every citizen is given the right to unite and create trade unions in order to protect common interests, guarantees are provided for the free activity of public associations. Such unions and associations can provide assistance in protecting violated rights not only by being active, but also, for example, by providing qualified legal assistance (Article 48 of the Constitution of the Russian Federation).

The last in the considered system of ways to protect the human right to freedom of speech and freedom is self-defense by a citizen of his rights when a person acts independently. This, for example, can be a citizen's appeal in the media, a public speech, participation in rallies, processions and picketing. In this case, the main principle operates, which provides the citizen with the opportunity to protect his rights and freedoms by any means not prohibited by law. So, according to Part 2 of Art. 45 of the Constitution of the Russian Federation, everyone has the right to defend their rights and freedoms in all ways not prohibited by law. In accordance with Art. 31 of the Constitution of the Russian Federation, citizens "have the right to assemble peacefully, without weapons, to hold meetings, rallies and demonstrations, processions and pickets."

A citizen's appeal to state and local authorities, institutions, enterprises and organizations should also be considered as a way of self-defense. The procedure for such applications is stipulated by the Federal Law dated 02.05.2006 No. 59-FZ "On the Procedure for Considering Applications of Citizens of the Russian Federation" [15].

\section{CONCLUSIONS}

All in all, the exercise and protection of the right to information, of course, to a large extent depends on the state, on the laws it adopts, on the activities of the competent authorities. It is the state that acts as the main guarantor of the implementation and protection of the right to freedom of speech and information, but the protection of rights should be supplemented in other ways, and the more such methods are available, the more effective the protection will be.

The activities of international instances allow you to control the domestic legal system, to seek justice for citizens when all legal remedies in their country have been exhausted. The activities of public associations whose purpose is to protect human rights and freedoms should be comprehensively supported and developed. The personal activity of citizens, as the main "consumers" of the right to freedom of speech and information, is no less important. The presence of a participant in legal relations (a citizen) of a high level of legal awareness and legal culture, an active position in terms of protecting their rights and interests, in general, can have a positive effect on the state of implementation of this right in the state.

\section{REFERENCES}

[1] M.A. Dubrovina, Zaschita konstitucionnogo prava na svobodu mysli I slova v sovremennoy Rossii: Ph. D Thesis, FGOU VPO, Saratov, 2007, 26 p.

[2] A.V. Popova, Konstitucionnoye pravo: kratkiy kurs lekciy, Yurayt, 2016, pp. 168-169.

[3] On the Prosecutor's Office of the Russian Federation: Federal Law of January 17, 1992 No. 2202-1 (as revised 
on February 6, 2020), Collected Legislation of the Russian Federation. 1995. No. 47. Art. 4472

[4] Code of the Russian Federation on Administrative Offenses of 30.12.2001 No. 195-FZ (as amended on 01.04.2020), Collected Legislation of the Russian Federation. 2002. No. 1. Art. one

[5] Appeal ruling of the Sverdlovsk Regional Court dated 06.12.2017 in case N 22-8747 / 2017 // ATP "Consultant Plus"

[6] 2019 Report of the Ombudsman for Human Rights in Russia (2019)

http://ombudsmanrf.org/content/doclad2019_Accessed 3 Nov 2020

[7] Judgment of the ECHR of March 5, 2019 "Case Skudaeva v. Russia" (complaint No. 24014/07), Bulletin of the ECHR. Russian edition 10 (2019)

[8] Judgment of the ECHR of April 16, 2019 "Case" Rebechenko (Rebechenko) v. Russia "(complaint No. 10257/17), Russian Chronicle of the ECHR 3(2019)

[9] Judgment of the ECHR of July 2, 2019 "The case of Novaya Gazeta and Milashina v. Russia" (application no. 45083/06) (2019) https://hudoc.echr.coe.int Accessed on 13 Nov 2020

[10] Judgment of the ECHR of October 8, 2019 "Case" Nadtoka v. Russia "(No. 2) (application No. 29097/08) (2019) http://hudoc.echr.coe.int/eng?i=001-196409 Accessed 3 Nov 2020

[11] Judgment of the ECHR of October 29, 2019 "Case" Novaya Gazeta and Borodyanskiy (Novaya Gazeta and Borodyanskiy) v. Russia "(application No. 42113/09) (2019) http://hudoc.echr.coe.int/eng?i=001-197208 Accessed on 11 Nov 2020

[12] Judgment of the ECHR of November 26, 2019 "Case" Savenko (Limonov) v. Russia "(complaint No. 29088/08) (2019) http://hudoc.echr.coe.int Accessed 3 Nov 2020

[13] ECHR judgment of 08.07.1986 "Lingens v.

Austria" (application no. 9815/82)

http://www.consultant.ru/cons/cgi/online.cgi?req=doc\& base $=$ INT $\& n=7171 \&$ dst $=4294967295 \&$ date $=04.05 .202$ 0 Accessed 3 Nov 2020

[14] Decree of the ECHR of 21.07.2005 "Case" Grinberg (Grinberg) v. Russian Federation "(complaint N 23472/03)

http://www.consultant.ru/cons/cgi/online.cgi?req=doc \& base $=$ ARB \&n $=24105 \& d s t=1000000001 \&$ date $=04.05 .2$ 020 Accessed on 3 Nov 2020
[15] On the procedure for considering appeals from citizens of the Russian Federation: Federal Law dated 02.05.2006 No. 59-FZ (as amended on 27.12.2018), Collected Legislation of the Russian Federation. 2006. No. 19. Art. 2060 